\title{
The Influence of Financial Literacy, Lifestyle and Self-Control on the Consumption Behavior of Economic Education Student
}

\author{
Ririn Eka Fariana ${ }^{1}$, Bayu Surindra², Zainal Arifin ${ }^{3}$ \\ ${ }^{1,2,3}$ Department of Economics Education, Nusantara PGRI University, Kediri, Indonesia
}

Corresponding Author: Ririn Eka Fariana

\begin{abstract}
The purpose of this study was to determine financial literacy and lifestyle as well as selfcontrol on the consumptive behavior of Economic Education students at UNP Kediri. This research approach used a quantitative approach as well as descriptive research techniques and multiple linear regressions. The sample collection used was a purposive sampling technique totaling 46 students. The results of this study indicated that financial literacy had a positive effect and had a significant value on student consumptive behavior, this can be seen in the value of Sig $0.027<0.05$. This lifestyle had a positive effect and had a significant value on the consumptive behavior of students, this could be seen in the value of Sig $0.038<0.05$. Self-control had a positive effect and had a significant value also on the consumptive behavior of students, this could be seen in the value of Sig $0.002<0.05$. Financial literacy, lifestyle and self-control had a significant and significant effect on the consumptive behavior of students, this could be seen in the value of Sig $0.000<0.05$.
\end{abstract}

Keywords: Financial Literacy, Lifestyle, Self Control, Consumptive Behavior.

\section{INTRODUCTION}

Daily needs follow human desires that are increasingly growing, humans must work to fulfill all their needs and desires. With the development of the era, everyone competes in meeting a need, not only needs but also competing in fulfilling his many desires to be owned or consumed to be able to satisfy desires only in terms of needs. With the frequency of shopping a person can be associated with consumptive behavior, consumptive behavior is a behavior that buys goods without having to reconsider and prefers to prioritize their desires rather than needs (1) Phenomena like this become a very serious threat, especially not only in adults but also in teenagers. This is because a person's consumption pattern is formed when he is a teenager. The final stage of adolescence is at the age of 18-21 years, this is an age that coincides with periods of transition and search for identity, where at this age teenagers seek and strive to achieve an ideal self pattern and experience a process of formation in behavior , (2). Consumptive behavior in students if executed continuously without any control over them will have a negative impact. One of the negative impacts of consumptive behavior is reducing the opportunity to save or waste, tend not to think about needs, and cause social jealousy. Late-level adolescents usually have a lot of pressure, starting from lifestyle pressures, environmental conditions and increasingly sophisticated technological developments so this can lead to the emergence of problems of consumptive behavior. Students or consumers should be able to make decisions and act rationally in meeting their every need. Consumptive behavior can be influenced by several factors including financial literacy and lifestyle as well as self-control. 
Good financial literacy will make consumers able to choose goods and manage finances as well as possible and can plan for the future. If consumers have a better understanding of financial literacy, they will usually be smarter when choosing an item comparing to people who do not understand financial literacy so this low financial literacy will have an impact on poor financial planning, the desire to save or invest for the future. In addition, it has an impact on the habit of excessive shopping or being trapped in consumptive behavior (3). This lifestyle tends to show consumption patterns that can reflect a person's choices and how to spend his money. This lifestyle has become a person's habit of changing a relatively short style and tends to go too far along with the development of smartphone technology, electronic commerse and social media, (4). Self-control describes an individual's decision which through a cognitive judgment to state the behavior that has been structured can improve outcomes and goals. This self-control has a close relationship with one's emotions where individuals are able to control their emotions and control themselves well (5).

Based on the results of preliminary interviews and observations of researchers, it was found that Economic Education students behaved consumptively with a statement where Economic Education students went to entertainment places such as spending free time at coffee shops with friends, restaurants and other hangout places. These are done by Economics Education students more than 4 times a month. In addition, the tendency of their consumptive behavior can be seen from the goods purchased to fulfill their desires not because of a need or saving, they like to shop because they are tempted by cheap prices, or are influenced by the existence of a discount, shop online, buy similar products, buy an item that is cheap that they think are unique without thinking about their needs. These behaviors are carried out 3 times or more in a month which will have a negative impact on the financial management of Economics Education Students because students are continuously led to do it so as not to save money. Economics Education students should be smarter in managing their finances because they have studied everything related to economics and finance, but here all Economics Education students tend not to implement what they have got related to financial management that students have in their daily lives. This Economics Education student should have good financial literacy when compared to other students

This consumptive behavior will always occur if students don't really understand how to control or control themselves in terms of desires, manage finances and how to live a frugal lifestyle, careful and minimalist lifestyle. This frugal lifestyle helps a person in making decisions so they do not spend money for unexpected or excessive. Economics Education students often use this lifestyle as the most basic motivation in buying something. And this lifestyle directs Economics Education students to all things that make them unneeded and leads students into actions that are only concerned with appearances only, as well as how to keep up with developments in the surrounding environment so that Economic Education students are no longer oriented to the future.

\section{LITERATURE REVIEW \\ Consumptive Behavior}

Consumptive behavior is a behavior that consumes excessively and definitely prioritizes a desire or can also be called a luxurious lifestyle (6). This desire to buy something arises because of seeing advertisements, and it is easy to be tempted by seductions in advertisements. Besides, it also happens because friends or follow moods or trends that are developing at this time and often someone puts their prestige forward so they don't feel out of date. Consumptive behavior can be influenced by internal and external factors. The internal factors are as follows (7). 1) Attitude, this is how a person responds to a given 
simulation, a person's attitude is much influenced by the environment. 2) Motivation, motivation is a strong impulse felt by someone in taking action, and so as not to behave consumptively. 3) Personality, mental, moral, physical, and human characteristics that describe each individual. 4) Learning and Memory, every day humans get information and try to remember the information in the memory for their needs.

\section{Financial Literacy}

Financial literacy is a good knowledge and understanding in managing finances appropriately; therefore one's education is very supportive to have knowledge and understanding related to financial literacy (8). Thus the existence of this financial literacy can make an effective financial decision in processing the right finances to obtain a prosperous life. Therefore, it can be concluded that financial literacy is a form of understanding and knowledge about financial management as well as possible to minimize future risks. Financial literacy includes four financial concepts (9) including: 1) General knowledge related to finance, 2) Knowledge related to money management, 3) Knowledge related to investment and savings, 4) Knowledge related to risk.

\section{Life Style}

Lifestyle is how individuals live, including how individuals use their money and allocate their time (10). Because it is often someone expresses into an activity, interests and opinions that have a direct influence on one's behavior. Lifestyle can be influenced by 2 factors; one of them includes internal factors as well as external factors, (7). Internal factors are attitudes, experiences as well as observations, personality, motives, self-concept, and perceptions, while external factors consist of social class, reference groups, family, and culture.

\section{Self Control}

Self-control is a form of individual skills in a sensitivity to read the situation and the environment. As for controlling and managing a person's behavioural factors in accordance with the conditions in presenting himself to socialize and control his behaviour (11). Self-control is an individual's ability to resist impulses and one's ability to control his behaviour when there is no self-control from the environment. Individuals or someone with high self-control is very concerned about the right way to behave in various situations (9). The types of self-control (1) are: 1) over control, 2) under control, 3) appropriate.

\section{MATERIALS \& METHODS}

The following is a conceptual framework consisting of independent variables: financial literacy, lifestyle and self-control, while the dependent variable is consumptive behavior.

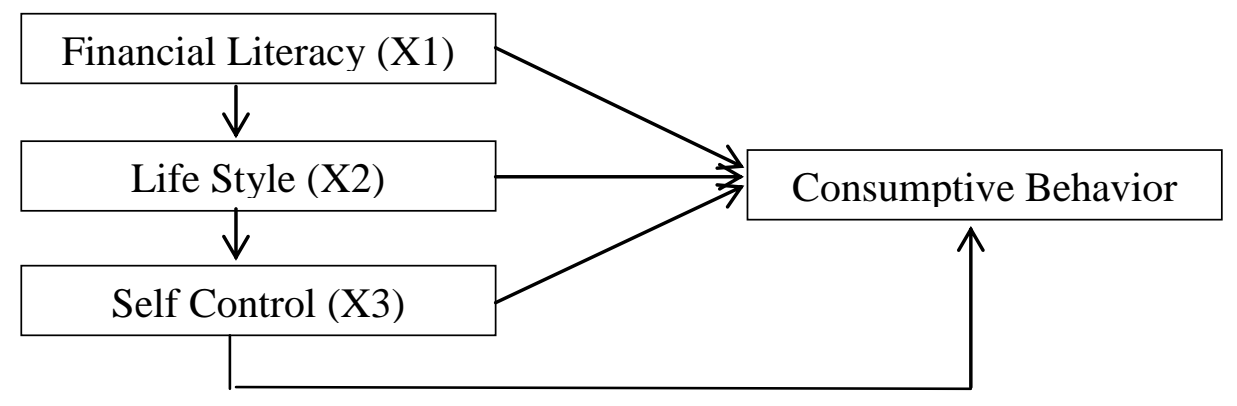

Figure1. Conceptual framework

This research was conducted at UNP Kediri, the population used was Economic
Education students class of 2017-2020 with a total of 58 students and the sample taken 
was 46 students using a purposive sampling technique which method of determining the respondents to be sampled based on certain criteria. The method of collecting data in this study used a questionnaire.

The approach used in this study was a quantitative approach and the research technique used was descriptive research and multiple linear regressions, which included normality test, multicollinearity test, heteroscedasticity test and autocorrelation test. To test the hypothesis using the $t$ test which was used to determine the effect of the independent variables on the dependent variable (financial literacy, lifestyle and self-control) partially affect consumptive behaviour, the $\mathrm{F}$ test was used to determine simultaneously where all independent variables had a simultaneous influence on consumptive behaviour.

\section{STATISTICAL ANALYSIS Normality test}

Based on the results of the normality test, the Kolmogorov-Smirnov sample test method with a normal distribution test can be seen in the table below:

Tabel 1 . Normality Test Data

\begin{tabular}{|l|l|l|}
\hline \multicolumn{2}{|l|}{ One-Sample Kolmogorov-Smirnov Test } \\
\hline $\mathrm{N}$ & Unstandardized Residual \\
\hline Normal Parameters & a,b & 46 \\
\cline { 2 - 3 } & Mean & .0000000 \\
\cline { 2 - 3 } & $\begin{array}{l}\text { Std. } \\
\text { Deviation }\end{array}$ & 1.76097902 \\
\hline \multirow{2}{*}{$\begin{array}{l}\text { Most Extreme } \\
\text { Differences }\end{array}$} & Absolute & .070 \\
\cline { 2 - 3 } & Positive & .044 \\
\cline { 2 - 3 } & Negative & -.070 \\
\hline Test Statistic & .070 \\
\hline Asymp. Sig. (2-tailed) & .200 \\
\hline \multicolumn{2}{|c|}{ Source: Primary Data Processed 2021 }
\end{tabular}

The table above shows that the normality test obtained asymp results. Sig of 0.200 which means $>0.05$ so it could be concluded that the data was normally distributed

\section{Heteroscedasticity Test}

The results of the heteroscedasticity test can be seen in the figure below:

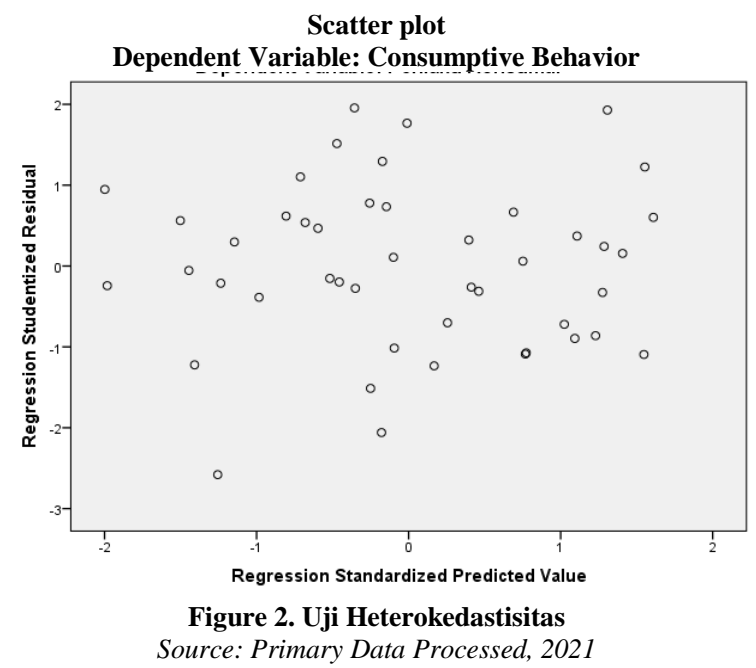

Based on heteroscedasticity, it could be seen that the points listed in the scatterplot graph did not form a clear pattern and were spread above and below the number 0 on the $\mathrm{Y}$ axis so that it can be concluded that there was no heteroscedasticity.

\section{Multicollinearity Test}

The results of the multicollinearity test can be presented in the figure below:

Table 2. Multicollinearity Test

\begin{tabular}{|c|c|c|c|c|c|c|c|c|}
\hline \multicolumn{9}{|c|}{ Coefficients $^{\mathrm{a}}$} \\
\hline \multicolumn{2}{|c|}{ Model } & \multicolumn{2}{|c|}{ Unstandardized Coefficients } & $\begin{array}{l}\text { Standardized Coefficients } \\
\text { Beta }\end{array}$ & $\mathbf{T}$ & Sig. & \multicolumn{2}{|c|}{ Collinearity Statistics } \\
\hline \multirow[t]{3}{*}{ Finan } & (Constant) & 20.456 & 7.827 & & 2.613 & .012 & & \\
\hline & Life Style & .434 & .203 & .268 & 2.140 & .038 & .999 & 1.001 \\
\hline & Self Control & .227 & .070 & .406 & 3.237 & .002 & .994 & 1.006 \\
\hline
\end{tabular}

Seen from the table above, it was known that the results of the multicollinearity test of the independent variables indicate that the tolerance value was greater than 0.10 while the VIF value was less than 10.00, therefore the conclusion means that it was free from multicollinearity. 
Ririn Eka Fariana et.al. The influence of financial literacy, lifestyle and self-control on the consumption behavior of economic education student.

\section{Autocorrelation Test}

The results of the autocorrelation test can be presented in the figure below:

Table 3. Autocorrelation Test

\begin{tabular}{|l|l|l|l|l|l|}
\hline \multicolumn{5}{|l|}{ Model Summary } \\
\hline Model & $\mathbf{R}$ & $\mathbf{R}$ Square & Adjusted R Square & Std. Error of the Estimate & Durbin-Watson \\
\hline 1 & $.587^{\mathbf{a}}$ & .344 & .297 & 1.823 & 2.274 \\
\hline a. Predictors: (Constant), Self Control, Life Style, Financial Literacy \\
\hline b. Dependent Variable: Consumptive Behavior \\
Source: Primary Data Processed, 2021 \\
\hline
\end{tabular}

Autocorrelation might not occur if the value of $d$ (Durbin Watson) $=2$, this positive autocorrelation can occur if the value of $\mathrm{d}$ (Durbin Watson) $=0$ and negative autocorrelation occurs when the value of $d$ (Durbin Watson) is close to 4 . It means that there was no autocorrelation between independent variable and dependent variable.

\section{RESULT}

\section{T-test Test (Partial)}

The results of the t-test test can be presented in the figure below:

Table 4. T-test Test (Partial)

\begin{tabular}{|c|c|c|c|c|c|c|}
\hline \multicolumn{7}{|c|}{ Coefficients $^{\mathrm{a}}$} \\
\hline \multirow{2}{*}{\multicolumn{2}{|c|}{ Model }} & \multicolumn{2}{|c|}{ Unstandardized Coefficients } & \multirow{2}{*}{$\begin{array}{l}\text { Standardized Coefficients } \\
\text { Beta }\end{array}$} & \multirow[t]{2}{*}{$\mathbf{t}$} & \multirow[t]{2}{*}{ Sig. } \\
\hline & & $\mathrm{B}$ & Std. Error & & & \\
\hline \multirow[t]{4}{*}{1} & (Constant) & 20.456 & 7.827 & & 2.613 & .012 \\
\hline & Financial Literacy & -.327 & .142 & -.288 & -2.298 & .027 \\
\hline & Life Style & .434 & .203 & .268 & 2.140 & .038 \\
\hline & Self Control & .227 & .070 & .406 & 3.237 & .002 \\
\hline \multicolumn{7}{|c|}{$\begin{array}{l}\text { Dependent Variable: Consumptive Behavior } \\
\text { Source: Primary Data Processed, } 2021\end{array}$} \\
\hline
\end{tabular}

\section{a. Financial Literacy (X1)}

This financial literacy variable had a positive and significant effect on the consumptive behavior of Economic Education Students at UNP Kediri. It was stated in the table that the value of Sig $0.027<0.05$ therefore Ho was rejected and $\mathrm{H}_{1}$ was accepted. This means that the higher the level of financial literacy, the lower the consumptive behavior of students

\section{b. Life Style (X2)}

This lifestyle variable had a positive and significant effect on the consumptive behavior of the Economic Education students of UNP Kediri. It was stated in the table that the value of Sig $0.038<0.05$ therefore Ho was rejected and $\mathrm{H}_{2}$ was accepted. This means that if the $\mathrm{X} 2$ variable or lifestyle is increased, the consumptive behavior variable will significantly increase.

c. Self Control (X3)

This self-control variable had a positive and significant effect on the consumptive behavior of Economic Education students at UNP Kediri. It was stated in the table that the value of Sig was $0.002<0.05$ so that Ho was rejected and $\mathrm{H}_{3}$ was accepted. This means that if the self-control variable is increased, the consumptive behavior variable will significantly increase.

\section{F Test (Simultaneous)}

The results of the t-test test can be presented in the figure below:

Table 5. F Test

\begin{tabular}{|c|c|c|c|c|c|c|}
\hline \multicolumn{7}{|c|}{ ANOVA $^{a}$} \\
\hline \multicolumn{2}{|c|}{ Model } & Sum of Squares & Df & Mean Square & $\mathbf{F}$ & Sig. \\
\hline \multirow[t]{3}{*}{1} & Regression & 73.257 & 3 & 24.419 & 7.349 & $.000^{\mathrm{b}}$ \\
\hline & Residual & 139.547 & 42 & 3.323 & & \\
\hline & Total & 212.804 & 45 & & & \\
\hline \multicolumn{7}{|c|}{ a. Dependent Variable: Consumptive Behavior } \\
\hline \multicolumn{7}{|c|}{$\begin{array}{l}\text { b. Predictors: (Constant), Self Control, Lifestyle, Financial Literacy } \\
\text { Source: Primary Data Processed, } 2021\end{array}$} \\
\hline
\end{tabular}


Based on table 4.21 , it is known that $\mathrm{F}_{\text {count }}$ is 7.349 with a significance level of 0.000 while $\mathrm{F}_{\text {table }}$ at the $95 \%$ or 0.05 confidence level was 2.82 so that $\mathrm{F}_{\text {count }}$ $7.349>\mathrm{F}_{\text {table }} 2.82$ and the significance level was $0.000<0.05$ indicating that the independent variable was financial literacy, Life style and self-control simultaneously had a significant effect on the consumptive behaviour of Economic Education Students, Nusantara PGRI University of Kediri.

\section{DISCUSSION}

\section{The Effect of Financial Literacy on Consumptive Behavior of Economic Education Students of UNP Kediri.}

Based on the results of the analysis of the data obtained, it shows that financial literacy has a positive and significant influence on consumptive behavior in Economics Education Students. This can be seen in the value of Sig $0.027<0.05$. From these results, it can be concluded that Ho is rejected and $\mathrm{H}_{1}$ is accepted. It means that the higher the level of student financial literacy, the lower the tendency to behave consumptively. If students have good financial literacy, they are able to process finances well. The existence of an influence between financial literacy on consumptive behavior is because Economic Education students are considered to have knowledge and insight about Economics which is closely related to managing finances well, so that students are able to manage their finances.

The results of this study is in line with previous research (3) which states that financial literacy has a positive and significant effect on consumptive behavior and according to (1) also states that financial literacy variables have a positive and significant influence on consumptive behavior. The result also in line with (12) which states research that financial literacy has a positive and significant influence on consumptive behavior.
2. The Influence of Lifestyle on Consumptive Behavior of Economic Education Students of UNP Kediri.

Based on the results obtained which indicate that lifestyle has a positive and significant influence on consumptive behavior in Economics Education Students. It can be seen from the value of Sig 0.038 $<0.05$. From these results it can be concluded that $\mathrm{Ho}$ is rejected and $\mathrm{H} 2$ is accepted. This means that if the lifestyle of Economic Education students at UNP Kediri is improved, consumptive behavior will also increase. Because the higher the lifestyle of Economic Education students, the higher their consumptive behavior will be. This lifestyle is very influential for the lives of Economics Education Students where students think that a lifestyle that is all-trend will make them feel more existent and confident in their appearance. The Economics Education students' lifestyle shows how they live, how they allocate their time and how to spend their money. So if students have an excessive lifestyle and even always follow the growing trend, they will experience financial difficulties. So students of Economics Education must be able to allocate it in order to avoid consumptive behavior.

The results of this study are in line with previous research of (13) which states that lifestyle also has a positive and significant effect on consumptive behavior. Meanwhile, according to (14) states that lifestyle has a significant positive influence on consumptive behavior.

\section{The Effect of Self-Control on Consumptive Behavior of Economic Education Students of UNP Kediri.}

Based on the results obtained, it shows that self-control has a positive and significant influence on the consumptive behavior of Economic Education Students. It can be seen at the value of Sig 0.002 $<0.05$. From these results, it can be concluded that $\mathrm{Ho}$ is rejected and $\mathrm{H}_{3}$ is accepted. It means that the higher selfcontrol of Economic Education students at 
UNP Kediri, the more intense the control of their behavior will be. So that with a control owned by Economics Education Students, they can make estimates of the behavior that will be carried out by students and make they are able to prevent excessive consumption. Self-control means that students can delay their willingness to carry out an activity. This self-control serves to encourage Economics Education students to save, manage and control behavioral factors according to their conditions. In addition, self-control is the ability to control excessive behavior.

The results of this study are in line with the results of research conducted by previous studies from (1) which states that lifestyle has a positive and significant effect on consumptive behavior.

\section{The Effect of Financial Literacy between Lifestyle and Self-Control on Consumptive Behavior of Economic Education Students of UNP Kediri.}

The results of the simultaneous test in this study indicate that the $F_{\text {count }}$ value of 7.349 is greater than $F_{\text {table }}$ which is 2.82 . So it can be concluded that $\mathrm{H}_{4}$ is accepted, Ho is rejected. It means that the three independent variables in this study including financial literacy (X1), lifestyle (X2) and self-control (X3) have a simultaneous or joint effect on consumptive behavior. The financial literacy between lifestyle and self-control is very important in preventing consumptive behavior if students are able to implement it in everyday life.

The results of this study are in line with the results of previous research from (12) which states that financial literacy, lifestyle, self-control have a significant and significant effect on consumptive behavior.

\section{CONCLUSION}

Based on the results of research and discussions that have been conducted, researchers can draw the following conclusions. (1) Partially there is a positive and significant influence between financial literacy and consumptive behavior in
Economics Education Students. With the value obtained Sig $0.027<0.05$ so there is a significant effect. (2) Partially there is a positive and significant influence between lifestyle and consumptive behavior in Economics Education Students. With the value obtained Sig $0.038<0.05$ so there is a significant effect. (3) Partially there is a positive and significant influence between self-control and consumptive behavior in Economics Education Students. With the value obtained Sig $0.002<0.05$ so there is a significant effect. (4) Simultaneously financial literacy, lifestyle and self-control have a significant influence on consumptive behavior in Economics Education Students. With the value obtained Sig $0.000<0.05$ so there is a significant effect.

\section{Acknowledgement: None}

\section{Conflict of Interest: None}

\section{Source of Funding: None}

\section{REFERENCES}

1. Fattah FA, Indriayu M, Sunarto. Pengaruh Literasi Keuangan dan Pengendalian Diri Terhadap Perilaku Konsumtif Siswa SMA Muhammadiyah 1 Karanganyar. J Pendidik Bisnis dan Ekon [Internet]. 2018;4(1):1121. Available from: https://jurnal.uns.ac.id/bise

2. Fatmawaty R. Memahami Psikologi Remaja. J Reforma. 2017;2(1):55-65.

3. Almas A. Pengaruh Financial Literacy, Pengendalian Diri, Teman Sebaya Dan Kondisi Sosial Ekonomi Orang Tua Terhadap Perilaku Konsumtif Pada Siswa Kelas XI SMA Negeri 2 Bae Kudus. 2019.

4. Kusnandar DL, Kurniawan D. Literasi Keuangan Dan Gaya Hidup Ibu Rumah Tangga Dalam Membentuk Perilaku Keuangan Keluarga Di Kota Tasikmalaya. Semin Nas dan Call Pap Sustain Compet Advant. 2018;(September):1-13.

5. Fadillah GF. Meningkatkan Pengendalian Diri Penerima Manfaat Melalui Bimbingan Kelompok Di Balai Rehabilitasi Mandiri. Vol. 2, Indonesian Journal of Guidance and Counseling - Theory and Application. 2013. 
Ririn Eka Fariana et.al. The influence of financial literacy, lifestyle and self-control on the consumption behavior of economic education student.

6. Yuniarti VS. Perilaku Konsumen Teori dan Praktik. Bandung: CV Pustaka Setia; 2015. $19,20,21,27,36,46,47,154,155,156$.

7. Priansa DJ. Perilaku Konsumen Dalam Persaingan Bisnis Kontemporer. Bandung: Alfabeta; 2017. 185, 190 p.

8. Izazi IM, Styaningrum F. Pengaruh Literasi Keuangan Terhadap Perilaku Konsumtif Dengan Self Control Sebagai Variabel Mediasi (Studi pada Mahasiswa Pendidikan Akuntansi Universitas PGRI Madiun). Rev Account Bus. 2020;1(1):35-42.

9. Ramadhani RH. Pengaruh Literasi Keuangan, Elektronic Money, Gaya Hidup, dan Kontrol Diri Terhadap Perilaku Konsumtif Mahasiswa Strata-1 Manajemen Universitas Sumatera Utara. Universitas Sumatera Utara Medan; 2019.

10. Kanserina D. Pengaruh Literasi Ekonomi dan Gaya Hidup Terhadap Perilaku Konsumtif Mahasiswa Jurusan Pendidikan Ekonomi UNDIKSHA. 2015; Volume 5(1).

11. Ghufron MN\& RRS. Teori-Teori Psikologi. Depok, Sleman, Jogjakarta: AR-RUZZ MEDIA; 2012. 21,22,29,31,32.
12. Wati NMI. Pengaruh Literasi Keuangan dan Gaya Hidup Terhadap Perilaku Konumtif Pegawai (Studi Kasus PT Pelabuhan Indonesia 1 (Persero) Medan). Universitas Muhammadiyah Sumatera Utara Medan; 2020.

13. Baroroh MA. Pengaruh Literasi Keuangan, Gaya Hidup Dan Pendapatan Orang Tua Terhadap Perilaku Manajemen Keuangan Santri Di Pondok Pesantren Madrosatul Qur'anil Aziziyah Semarang. Fakultas EKkonomi Dan Blisnis Islam Universitas Islam Negeri Walisongo Semarang. 2019.

14. Danang Krisdiantoro, Dr. H. Susanto MS, Tri Maryati, S.E. MM. Pengaruh Iklan Online , Konformitas , dan Gaya Hidup Terhadap Perilaku Konsumtif. 2016;81, 91.

How to cite this article: Fariana RE, Surindra B, Arifin Z. The influence of financial literacy, lifestyle and self-control on the consumption behavior of economic education student. International Journal of Research and Review. 2021; 8(8): 496-503. DOI: https://doi.org/10. 52403/ijrr.20210867 